\title{
Book Review: \\ Shahi, D. (2018). Kautilya and Non-Western IR Theory. Palgrave Pivot, 167 p.
}

\author{
A.V. Kanisetti \\ The Takshashila Institution, Bangaluru, India
}

Rediscovered by accident in the early 20 th century, the "Arthashastra" is one of the most remarkable ancient Indian texts. It was originally compiled by Kautilya who served as the prime minister of an early North Indian emperor. Kautilya's Arthashastra was repeatedly expanded and re-adapted till the 3rd century CE. It eventually turned out to be an encyclopaedic text that contains everything from comprehensive descriptions of complex bureaucracies, to firm statements on the duties and responsibilities of the king, to meticulous instructions on fortification and war-elephant diets, and to theoretical explanations of interstate relations. Given its distinct position as a foundational South Asian text on polity and policy, referenced for centuries after ${ }^{1}$, Kautilya's Arthashastra is increasingly evoked as a reservoir of those non-Eurocentric ideas that can possibly transform the academic discipline of International Relations (IR) from a field dominated by theories grounded in Western historical experiences into a "Global" one.

However, rather than seeing Kautilya as a genuine component of non-Western intellectual tradition in his own right, his conceptualizations - such as the famous "circle of kings" - have been inconsiderately used to shoehorn him into a pre-existing school: that is, "Political Realism". Ever since Max Weber (who was the first influential Western scholar to identify Arthashastra as a seminal text on political thought) labeled Kautilya as "Machiavellian" [Weber 1919], the later generations of Indian and Western scholars

\footnotetext{
1 Kamandaka, the author of 'Nitisara' (c. 5th-6th CE), explicitly refers to Kautilya as his preceptor. Likewise, Somaveda, the author of 'Nitivakyamrita' (c. 10th CE), considerably draws inspirations from Kautilya's Arthashastra. In fact, both these ancient Indian texts remained highly influential in South Asian strategic thought.
}

(including Benoy Kumar Sarkar [1919] and Roger Boesche [2003]) reiterated the tendency to depict Kautilya as an unscrupulous Machiavellian schemer ${ }^{2}$ devoted to the Political Realist goal of maximization of power at all costs. Even though Kautilya comes from a specific non-Western historical tradition and overtly situates his account of state behavior on a non-Western philosophical base (different from the Western one), the voluminous academic works on Kautilya's Arthashastra have stripped it of its historical and philosophical contexts, thereby misleadingly interpreting it as a replica of Western Political Realism.

Uncritical studies on Kautilya's Arthashastra abound, using a tautological approach to fit models thousands of years old to a drastically different modern world (or say, post-modern world) in an interesting but not in a revolutionary way. Quite refreshingly, a scholar has stepped up to articulate a clear path for understanding Kautilya's Arthashastra on its own merits, starting with its "philosophical presuppositions" rather than its "political conclusions" - as Deepshikha Shahi's Kautilya and NonWestern IR Theory sets out to "reinvent Arthashastra" [Shahi 2018: 131], foreground its "extra-Political Realist elements" [Shahi 2018: 129], and formulate a Kautilyan "non-Western eclectic theory" for grasping contemporary global politics [Shahi 2018: 137], it most certainly lays the foundation for a new era in Global IR.

2 Notwithstanding a few recent studies that attempt to extract a 'moral theory' out of Machiavelli's work [Lamus 2016], the term "Machiavellian" is still popularly accepted in terms of its established dictionary meaning — that is, 'cunning, scheming and unscrupulous, especially in politics'. 


\section{Kautilyan Worldview: A New Old Philosophy}

Considering that Kautilya is quite upfront with his philosophical base (as he clearly mentions it at the very beginning of Arthashastra), it is surprising that most IR scholars do not attempt to examine this philosophical base before jumping to a Political Realist re-reading of Kautilya's Arthashastra which, in turn, unjustifiably assigns it an "essentially immoral, deterministic, and nativist character? [Shahi 2018: 6]. This is one of the key problems that Shahi tackles. To her, Kautilya is representative of a non-Western philosophical base which contains a different set of assumptions and arrives at a different set of conclusions. Kautilya's philosophical base is a fusion of contemporaneous South Asian bodies of thought namely Sāmkhya, Yōga and Lokāyata.

The "orthodox" schools of Sāmkhya and Yōga hold that primordial matter evolved from interaction with the spirit / soul; thus, there is a division between the soul and the bodily elements to which it is attached, and calls for moderation and non-violence to achieve well-being of both.

To this, Kautilya adds an apparently contradictory non-orthodox school of Lokāyata, which is relentlessly empirical, interested in material wealth and comfort, and admits to no independent soul or even consciousness beyond the body. From a purely pragmatic standpoint, Lokāyata also believes in moderation and non-violence to achieve well-being (otherwise a would-be hedonist would die of gluttony before she is able to really enjoy life) ${ }^{3}$. At their intersection, shows Shahi, is the Kautilyan worldview which demands that humans - whether they are made of bodies or souls or both - must be provided for both materially and spiritually.

Western "realpolitik", Shahi points out, seems to be based on an Augustinian view that the world is fallen thanks to the original sin of humankind and that one must either "eat or be eaten" no matter what the moral costs. By contrast, Western "moralpolitik" is a reactionary response that criticizes the use of violence and prefers the use of morally superior methods. There is a wide and an ever-present gulf between

3 For a detailed experiential analysis of Sāṃkya and Yōga, see: [Burley 2007]. For a critical study of the nuances of Lokayata and its relationship to other Indian philosophical traditions, see: [Gokhale 2015]. the two. But for Kautilya, argues Shahi, there is no gulf between the ideas of realpolitik and moralpolitik (despite the Western claim that Kautilya is the first "unrelenting Political Realist" and other similarly dramatic proclamations).

In fact, Kautilya uses a material-spiritual framework to temper all his ostensibly amoral methods. Furthermore, his amoral methods serve moral goals. And this perspective clearly informs every aspect of the Arthashastra - assassinations, for example, help stabilise the king's rule, but this is not meant to help the king cling to power for power's sake rather, it is meant to ensure stability in the kingdom, and ultimately, the welfare of the subjects ${ }^{4}$. Shahi arouses the same material-spiritual framework to credibly refute those geographically deterministic analyses of Kautilya's Arthashastra whereby a neighboring state is to be compulsorily visualized as an enemy state.

Most importantly, Shahi shows that the philosophical base espoused by Kautilya appears to have guided the behaviour of ancient Indian states. The example she chooses is the Mauryan Empire whether Ashoka's Mauryan Empire was consciously following Kautilya's Arthashastra or not, it seemed to pursue a peculiar Kautilya-inspired exemplar of domestic governance and international relations. At the outset, Shahi's investigation of Ashoka's rule as the historical test case for Kautilyan thought (or conflation of Ashoka's Buddhist ethics with Kautilyan philosophy) might seem problematical. However, this problematical aspect gets diluted when Shahi skips a whole-sale amalgamation of Ashoka's Buddhist ethics and Kautiyan philosophy. She, rather, recasts Ashoka's rule as an "eclectic" mix of the selected commonalities between "Kautilyan thought" (usually depicted as realpolitik); and "Buddhist thought" (generally accepted as moralpolitik) [Shahi 2018: 57]. By way of mainstreaming the eclectic philosophical base of Kautilya's Arthashastra, Shahi has struck

4 This might seem strikingly reminiscent of the idea of the social contract — which is, incidentally, quite evident in many ancient Indian texts, where kings are chosen by the gods or people to ensure the safety of their subjects and are empowered to collect taxes and inflict punishment to do so. Though the foundational legend used to justify kingship would later change, that change happened well after the compilation of the Arthashastra. For an elaborate discussion on this issue, see: [Singh 2002]. 
upon a rich, previously unexplored literary-philosophical vein which bears tremendous potential to contribute to the ongoing discourses on Global IR.

\section{Kautilya's Eclecticism: A Passage to Global International Relations}

With the positioning of Kautilya as an eclectic thinker who sits astride the realist - reflectivist debate (or realpolitik - moralpolitik debate), Shahi offers a platform for innovative scholarship which can move the academic discipline of IR beyond the feedback loops into which it seems to have settled of late. It also provides a breath of fresh air to those Indian studies of Arthashastra which have inclined towards nativism, proclaiming Kautilya's primacy and focussing on the fragments which seem most recognisable to present-day IR rather than studying the text as a whole to discern the nuances of ancient Indian strategic thinking. While the scholars like Kanti Bajpai are wary of nativism and therefore skeptical about an Indianized foregrounding of Kautilya in IR [Bajpai 2005], the scholars like Balbir Sihag promote a nativist (or rigidly Indianized) foregrounding of Kautilya in IR [Sihag 2004].

Shahi considers both these scholarly attitudes as unfruitful: she thinks Kautilya's work must be acknowledged as an Indian intellectual resource, but the "non-Western eclectic theory" emanating from Kautilya's work must be recognized as not only "Indian IR" (capable of explaining Indian realities) but also "Global IR" (capable of explaining the realities across the globe).

However, Shahi does not deny miscellaneous traces of present-day IR theories in Kautilya's Arthashastra (such as Political Realism, Social Constructivism, and Eclecticism) - for instance, she asserts that Kautilya's "circle of kings" is based on both "neorealist capabilities" and "social constructivist identities" precisely because one can witness a shift in identities with the change in capabilities; thus, identities and capabilities are correlated in both
Wendt's Social Constructivism and Kautilya's "circle of states". Nevertheless, Shahi discards a thoroughly "presentist" study of Kautilya's Arthashastra by way of bringing forth its "unconventional traits" (that is, the traits which are "not present" in either Western Political Realism or Social Constructivism).

For instance, Shahi demonstrates how Kautilya's Arthashastra is "unusual in the way it withstands the rational / prudent self-interests of states defined in terms of power, and yet goes ahead and establishes the abstract universal ideals of the protection of the earth as a necessary condition for fulfillment of those rational / prudent self-interests", thereby destabilizing the power vs. morality debates that perpetually affects Western IR [Shahi 2018: 118]. Likewise, she elucidates how Kautilya's Arthashastra "puts maximum emphasis upon the detached personal (re)actions of the rulers of international politics (irrespective of their institutional status as state or nonstate actors)", thereby trivializing the issue of institutional superiority / inferiority of state or non-state actors in international politics that continues to baffle Western IR [Shahi 2018: 119].

Shahi has developed a convincing theoretical and methodological foundation that could probably renovate the field of Arthashastra studies. But more importantly, this theoretical and methodological foundation can be used to study other ancient Indian theories of state behaviour and develop larger ideas on international relations based on non-Western philosophies and historical experiences. Though it will take a lighthouse to shine a light through the many questions that have been asked and remain to be asked, Shahi provides a lamp to guide the way. Overall, Kautilya and Non-Western IR Theory is an important contribution to Global, and especially Indian, understandings of strategic culture. As per Shahi's openly expressed intention, the book stands to creatively enhance the status of "both Indian IR and Global IR" [Shahi 2018: 143].

\section{References}

Bajpai, K. (2005). International Studies in India: Bringing Theory (Back) Home. In: International Relations in India: Bringing Theory Back Home / Ed. by K. Bajpai, S. Mallavarapu. New Delhi: Orient Longman.

Boesche, R. (2003). The First Great Political Realist: Kautilya and His Arthashastra. Lanham: Lexington Books.

Burley, M. (2007). Classical Samkhya and Yoga: An Indian Metaphysics of Experience. London and New York: Routledge. Gokhale, P. (2015). Lokāyata / Cārvāka: A Philosophical Inquiry. Oxford: Oxford University Press.

Lamus, F. (2016). Machiavelli's Moral Theory: Moral Christianity versus Civic Virtue. MA Thesis. Duke University. 
Sarkar, B.K. (1919). The Hindu Theory of International Relations. The American Political Science Review, 13 (3), $400-414$.

Shahi, D. (2018). Kautilya and Non-Western IR Theory. Palgrave Pivot. https://doi.org/10.1007/978-3-030-01728-6

Sihag, B.S. (2004). Kautilya on the Scope and Methodology of Accounting, Organizational Design and the Role of Ethics in Ancient India. Accounting Historians Journal, 31 (2), 125-148.

Singh, U. (2002). Political Violence in Ancient India. Harvard: Harvard University Press.

Weber, M. (1919). Politics as a Vocation. A Speech Delivered at Munich University. In: Max Weber: Selections in Translation / Ed. by W. Runciman. Cambridge: Cambridge University Press.

Received: 03.05.2019

For citations: Kanisetti, A.V. (2019). Book Review: Shahi, D. (2018). Kautilya and Non-Western IR Theory. Palgrave Pivot, 167 p. Vestnik RUDN. International Relations, 19 (2), 320-323. DOI: 10.22363/2313-0660-2019-19-2-320-323.

About the author: Anirudh V. Kanisetti - Research analyst, The Takshashila Institution, Bangaluru, India.

DOI: $10.22363 / 2313-0660-2019-19-2-320-323$

\title{
Рецензия на монографию: \\ Shahi D. Kautilya and Non-Western IR Theory. Palgrave Pivot, 2018. 167 p.
}

\author{
А.В. Канисетти \\ Институт Такшасила, Бангалор, Индия
}

Дата поступления статьи: 03.05.2019

Для цитирования: Канисетти А.В. Рецензия на монографию: Shahi D. Kautilya and Non-Western IR Theory. Palgrave Pivot, 2018. 167 p. // Вестник Российского университета дружбы народов. Серия: Международные отношения. 2019. T. 19. № 2. C. 320 -323. DOI: 10.22363/2313-0660-2019-19-2-320-323.

Сведения об авторе: Анирудх Канисетти - аналитик-исследователь в Институте Такшасила, Бангалор, Индия. 